\title{
Front Matter: Volume 7691
}

, "Front Matter: Volume 7691," Proc. SPIE 7691, Space Missions and Technologies, 769101 (19 May 2010); doi: 10.1117/12.864060

SPIE Event: SPIE Defense, Security, and Sensing, 2010, Orlando, Florida, United SPIE. States 


\section{PROCEEDINGS OF SPIE}

\section{Space Missions and Technologies}

Joseph Lee Cox

Manfred G. Bester

Wolfgang Fink

Editors

5-6 April 2010

Orlando, Florida, United States

Sponsored and Published by

SPIE 
The papers included in this volume were part of the technical conference cited on the cover and title page. Papers were selected and subject to review by the editors and conference program committee. Some conference presentations may not be available for publication. The papers published in these proceedings reflect the work and thoughts of the authors and are published herein as submitted. The publisher is not responsible for the validity of the information or for any outcomes resulting from reliance thereon.

Please use the following format to cite material from this book:

Author(s), "Title of Paper," in Space Missions and Technologies, edited by Joseph Lee Cox, Manfred G. Bester, Wolfgang Fink, Proceedings of SPIE Vol. 7691 (SPIE, Bellingham, WA, 2010) Article CID Number.

ISSN 0277-786X

ISBN 9780819481559

Published by

SPIE

P.O. Box 10, Bellingham, Washington 98227-0010 USA

Telephone +1 3606763290 (Pacific Time) · Fax +1 3606471445

SPIE.org

Copyright (C) 2010, Society of Photo-Optical Instrumentation Engineers

Copying of material in this book for internal or personal use, or for the internal or personal use of specific clients, beyond the fair use provisions granted by the U.S. Copyright Law is authorized by SPIE subject to payment of copying fees. The Transactional Reporting Service base fee for this volume is $\$ 18.00$ per article (or portion thereof), which should be paid directly to the Copyright Clearance Center (CCC), 222 Rosewood Drive, Danvers, MA 01923. Payment may also be made electronically through CCC Online at copyright.com. Other copying for republication, resale, advertising or promotion, or any form of systematic or multiple reproduction of any material in this book is prohibited except with permission in writing from the publisher. The CCC fee code is 0277-786X/10/\$18.00.

Printed in the United States of America.

Publication of record for individual papers is online in the SPIE Digital Library.

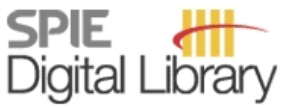

SPIEDigitalLibrary.org

Paper Numbering: Proceedings of SPIE follow an e-First publication model, with papers published first online and then in print and on CD-ROM. Papers are published as they are submitted and meet publication criteria. A unique, consistent, permanent citation identifier (CID) number is assigned to each article at the time of the first publication. Utilization of CIDs allows articles to be fully citable as soon they are published online, and connects the same identifier to all online, print, and electronic versions of the publication. SPIE uses a six-digit CID article numbering system in which:

- The first four digits correspond to the SPIE volume number.

- The last two digits indicate publication order within the volume using a Base 36 numbering system employing both numerals and letters. These two-number sets start with 00, 01, 02, 03, 04, $05,06,07,08,09,0 A, 0 B \ldots 0 Z$, followed by 10-1Z, 20-2Z, etc.

The CID number appears on each page of the manuscript. The complete citation is used on the first page, and an abbreviated version on subsequent pages. Numbers in the index correspond to the last two digits of the six-digit CID number. 


\section{Contents}

$\checkmark \quad$ Conference Committee

\section{ON-ORBIT OPERATIONS}

769102 Intersatellite radiometric calibration for a satellite radar scatterometer [7691-01]

R. Hanna, L. Jones, Univ. of Central Florida (United States)

769103 Use of environmental impacts in sensor scheduling [7691-02]

P. J. Shea, Black River Systems Co., Inc. (United States); M. Gioioso, H. E. Snell, Atmospheric and Environmental Research, Inc. (United States)

769104 A method for studying the effects of thermal deformations on optical systems for space application [7691-03]

E. Segato, CISAS, Univ. degli Studi di Padova (Italy); V. Da Deppo, CNR-IFN, Univ. degli Studi

di Padova (Italy); S. Debei, Univ. degli Studi di Padova (Italy); G. Cremonese, INAF-

Osservatorio Astronomico di Padova (Italy)

769105 Zero-G experimental validation of a robotics-based inertia identification algorithm [7691-04] J. J. Bruggemann, I. Ferrel, G. Martinez, P. Xie, O. Ma, New Mexico State Univ. (United States)

\section{SPACE QUALIFIED COMPONENTS}

769109 Performances of AIGaN-based focal plane arrays from 10nm to 200nm [7691-07]

J.-L. Reverchon, S. Bansropun, J.-P. Truffer, E. Costard, Alcatel-Thales III-V Lab. (France);

E. Frayssinet, J. Brault, J.-Y. Duboz, CNRS-CRHEA (France); A. Giuliani, M. Idir, Synchrotron SOLEIL (France)

7691 OA Print-and-play: a new paradigm for the nearly-instant aerospace system [7691-08]

K. H. Church, C. M. Newton, A. J. Marsh, nScrypt, Inc. (United States); E. W. MacDonald, C. D. Soto, The Univ. of Texas at El Paso (United States); J. C. Lyke, Air Force Research Lab. (United States)

\section{COMMUNICATIONS, COMMANDING, AND CONTROL}

7691 OC Combined differential demodulation schemes for satellite-based AIS with GMSK signals [7691-10]

Z. Zhang, J. Weinfield, T. Soni, Argon ST, Inc. (United States)

7691 OD Cooperative controls with intermittent communication [7691-11]

D. Shen, G. Chen, DCM Research Resources, LLC (United States); J. B. Cruz, Jr., The Ohio State Univ. (United States); K. Pham, E. Blasch, Air Force Research Lab. (United States);

R. Lynch, Naval Undersea Warfare Ctr. (United States) 
7691 OF Compact time-resolved remote Raman system for detection of anhydrous and hydrous minerals and ices for planetary exploration [7691-13]

S. K. Sharma, A. K. Misra, T. E. Acosta, P. G. Lucey, Univ. of Hawai'i (United States);

M. N. Abedin, NASA Langley Research Ctr. (United States)

$76910 G \quad$ Optical receiver design for the ground to space laser time transfer [7691-25]

I. Prochazka, J. Blazej, P. Fort, J. Kodet, Czech Technical Univ. in Prague (Czech Republic)

\section{SPACE ENVIRONMENT AND SITUATIONAL AWARENESS}

$769101 \quad$ The influence of uncertainties of attitude sensors on attitude determination accuracy by linear covariance analysis [7691-16]

J. Blomqvist, Cranfield Univ (United Kingdom); R. Fullmer, Utah State Univ. (United States)

$76910 \mathrm{~J} \quad$ Space object tracking with delayed measurements [7691-17]

H. Chen, Univ. of New Orleans (United States); D. Shen, G. Chen, DCM Research Resources, LLC (United States); E. Blasch, K. Pham, Air Force Research Lab. (United States)

7691 OK Canary: ion spectroscopy for ionospheric sensing [7691-18]

H. S. Feldmesser, M. A. G. Darrin, R. Osiander, L. J. Paxton, A. Q. Rogers, J. A. Marks, The Johns Hopkins Univ. Applied Physics Lab. (United States); M. G. McHarg, R. L. Balthazor, L. H. Krause, J. G. FitzGerald, U.S. Naval Research Lab. (United States)

$76910 \mathrm{~L} \quad$ Intelligent sensor tasking for space collision mitigation (Invited Paper) [7691-19]

J. R. Henderson, S. Nikolaev, D. W. Phillion, W. H. De Vries, A. J. Pertica, S. S. Olivier, Lawrence Livermore National Lab. (United States)

\section{POSTER SESSION}

7691 OP Optimize the space combinations of measure-vectors of the integrated star-sensor/gyro systems for spacecrafts [7691-22]

X. Li, J. Yang, J. Yang, H. Jia, Y. Jiao, Y. Yang, S. Guo, National Univ. of Defense Technology (China); M. Yang, D. Wang, Q. Fan, China Academy of Space Technology (China)

Author Index 


\title{
Conference Committee
}

\author{
Symposium Chair
}

Michael T. Eismann, Air Force Research Laboratory (United States)

Symposium Cochair

William Jeffrey, HRL Laboratories, LLC (United States)

Conference Chairs

Joseph Lee Cox, Missile Defense Agency (United States)

Manfred G. Bester, University of California, Berkeley (United States)

Wolfgang Fink, California Institute of Technology (United States)

Program Committee

Marco Bacaloni, The Aerospace Corporation (United States)

Thomas George, ViaLogy PLC (United States)

Steven C. Gordon, Georgia Tech Research Institute (United States)

Richard T. Howard, NASA Marshall Space Flight Center (United States)

David Irvin, U.S. Air Force (United States)

Jeffrey L. Janicik, Innoflight Inc. (United States)

Ou Ma, New Mexico State University (United States)

Greg J. Meyer, U.S. Air Force (United States)

Pejmun Motaghedi, The Boeing Company (United States)

Khanh D. Pham, Air Force Research Laboratory (United States)

Michael J. Sholl, University of California, Berkeley (United States)

Amanda Vaughn, Kinsey Technical Services, Inc. (United States)

Marco Villa, Space Exploration Technologies (United States)

Session Chairs

Introduction

Manfred G. Bester, University of California, Berkeley (United States)

On-Orbit Operations

Manfred G. Bester, University of California, Berkeley (United States)

Joseph Lee Cox, Missile Defense Agency (United States)

Launch Services

Manfred G. Bester, University of California, Berkeley (United States)

David Irvin, U.S. Air Force (United States) 
Space Qualified Components

Michael J. Sholl, University of California, Berkeley (United States)

Manfred G. Bester, University of California, Berkeley (United States)

Communications, Commanding, and Control

Khanh D. Pham, Air Force Research Laboratory (United States)

Manfred G. Bester, University of California, Berkeley (United States)

Space Environment and Situational Awareness

Khanh D. Pham, Air Force Research Laboratory (United States)

Greg J. Meyer, U.S. Air Force (United States)

Optics Designs for Space Telescopes

Manfred G. Bester, University of California, Berkeley (United States)

David Irvin, U.S. Air Force (United States) 